\title{
Safety evaluation of the antimicrobial peptide bovicin HC5 orally administered to a murine model
}

\author{
Aline Dias Paiva ${ }^{1}$, Kenner Morais Fernandes², Roberto Sousa Dias², Alípio dos Santos Rocha², \\ Leandro Licursi de Oliveira ${ }^{2}$, Clóvis Andrade Neves², Sérgio Oliveira de Paula ${ }^{2}$ and Hilário Cuquetto Mantovani ${ }^{*}$
}

\begin{abstract}
Background: Bovicin HC5 is an antimicrobial peptide that shows a broad spectrum of activity and potential for biotechnological and therapeutic applications. To gain insight about the safety of bovicin HC5 application, the histological and immunostimulatory effects of orally administrated bovicin HC5 to BALB/c mice were evaluated. BALB/C mice were divided into three groups: negative control (NC group); mice given purified bovicin HC5 (Bov group); mice given ovalbumin (positive control, PC group; a murine model of enteropathy). The mice were initially pre-sensitized, and PBS, bovicin HC5 or ovalbumin were administered for 30 days by daily gavages. Histological and morphometric analysis were performed and the relative expression of cytokines was analyzed by real-time RT-PCR.

Results: The oral administration of bovicin $\mathrm{HC} 5$ to BALB/C mice reduced weight gain and caused alterations in the small intestine, although absorptive changes have not been detected. The number of total goblet cells and the mucopolysaccharides production were not affected by bovicin HC5 administration. A hypertrophy of Paneth cells and an increase in the number of mitotic cells were observed in Bov group, while the number of mast cells remained unaltered. Increased expression of TNF-a, INF- $\gamma$ and IL-12 was observed in the small intestine upon bovicin HC5 administration.
\end{abstract}

Conclusion: Bovicin HC5 has only minor effects on intestinal permeability and did not elicit an allergenic response upon oral administration to animal models. Considering the low in vivo toxicity of bovicin HC5, it might be a good candidate for enteral applications.

Keywords: Bacteriocin, Lantibiotic, Streptococcus bovis HC5, BALB/c mice, Ovalbumin

\section{Background}

Bacteriocins are antimicrobial peptides produced by many species of bacteria and some members of the Archaea domain. Nisin, the most well-known bacteriocin, is produced by Lactococcus lactis strains and it belongs to the lantibiotic class of bacteriocins; nisin has GRAS status (Generally Recognized as Safe) and is currently the only bacteriocin approved for use as a food preservative [1]. Other bacteriocins, such as pediocin $\mathrm{PA}-1 / \mathrm{AcH}$ and lacticin 3147, are also commercially available, but are marketed as fermentates of lactic acid bacteria (LAB) having GRAS status [2].

\footnotetext{
* Correspondence: hcm6@ufv.br

'Departamento de Microbiologia, Universidade Federal de Viçosa, Viçosa,

Minas Gerais, Brazil

Full list of author information is available at the end of the article
}

The targeted mechanism of action and the relatively low propensity to select resistant bacteria are attractive properties of the lantibiotics. Moreover, previous studies have demonstrated the efficacy of many lantibiotics against target bacteria [3] and also the potential for biotechnological and therapeutic applications of these peptides [4]. Despite the good results obtained in vitro, the large scale application of lantibiotics remains limited due to the lack of data regarding clinical aspects, including the destiny of the peptides after ingestion, the loss of antimicrobial activity, the cytotoxicity and the immunostimulatory effects triggered by these peptides in vivo [5].

In order to evaluate the in vivo toxicity, an antimicrobial peptide should be administered daily and repeatedly to an animal model for a required period of time [6,7], and the route of administration should be the same proposed for use in vivo [8]. Because lantibiotics generally

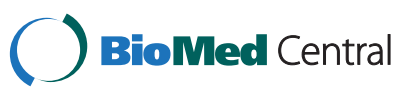


have low molecular mass and little intrinsic immunogenicity, coupling of these peptides to protein carriers or the use of adjuvants can be useful strategies to enhance the immunogenicity $[9,10]$.

Bovicin HC5, a lantibiotic produced by the ruminal bacterium Streptococcus bovis HC5, has desirable properties, such as broad spectrum of activity, stability to low $\mathrm{pH}$ and high temperatures $[11,12]$. The mechanism of action of bovicin HC5 was recently elucidated and it is based on the specific interaction with lipid II molecule, leading to inhibition of the bacterial cell wall synthesis and eventually to pore-formation [13]. Previous results indicated that the in vitro toxicity of bovicin HC5 against mammalian cells is comparable to nisin [14]. Bovicin HC5 has been suggested as a potential alternative to classical antibiotics in livestock production and as an additive for food preservation $[15,16]$.

To gain insight about the safety use of bovicin HC5 on animal hosts, we analyzed the effects of orally administrated bovicin $\mathrm{HC} 5$ to $\mathrm{BALB} / \mathrm{c}$ mice, focusing on gastrointestinal permeability, morphological alterations in the GI tract and the immunostimulatory effects of the peptide. We used a murine model of enteropathy induced by sensitization to compare the effects caused by the administration of bovicin HC5.

\section{Results}

The administration of bovicin HC5 induces less weight gain in $\mathrm{BALB} / \mathrm{c}$ mice

The weight of BALB/c mice was monitored during the trial period to verify if the sensitization followed by challenge with bovicin HC5 or ovalbumin affected weight gain of the animals, which could indicate clinical manifestation of allergy or gastrointestinal disorders. Symptoms as diarrhea, intestinal bleeding or rectal prolapsed were not observed.

Prior to the experiment, no significant differences were detected among the average weight of the mice $(18.5,18.4$ and $18.3 \mathrm{~g}$ to $\mathrm{NC}$, Bov and $\mathrm{PC}$ groups, respectively). In the $\mathrm{NC}$ group, the average mice weight ranged from $18.5 \pm$ $0.35 \mathrm{~g}$ (day 0 ) to $20.8 \pm 0.31 \mathrm{~g}$ (day 58 ), or a weight gain of $11.01 \%$ along the trial period.

Animals sensitized with bovicin HC5 or ovalbumin gained weight only during the three initial weeks of the experiment, before starting the oral administration of bovicin HC5 or ovalbumin. After 58 days of experiment, the percentage of weight gain was 0.91 and $-1.8 \%$ for animals of the Bov and PC groups, respectively, which was significantly lower compared to the NC group $(\mathrm{p}<0.05)$. There was no significant difference of weight gain between the Bov and PC groups (Figure 1).

\section{Gastrointestinal permeability is not altered upon oral administration of bovicin $\mathrm{HC} 5$}

No $\beta$-lactoglobulin ( $\beta$-LG) was detected in serum samples obtained before $\beta$-LG administration or in samples from the $\mathrm{NC}$ group after administration of $\beta$-LG. In sera obtained from animals of the PC group, significant amounts of $\beta$-LG were detected after $0.5,1$ and $2 \mathrm{~h}$ of $\beta$-LG administration $\left(3.47 \mathrm{mg} \mathrm{ml}^{-1}, 3.53 \mathrm{mg} \mathrm{ml}^{-1}\right.$ and $12.14 \mathrm{mg} \mathrm{ml}^{-1}$, respectively). After $5 \mathrm{~h}$ of administration, $\beta$-LG could not be detected in the PC group, suggesting that $\beta$-LG clearance required at least $5 \mathrm{~h}$ to occur. In the Bov group, low concentrations of $\beta$-LG $\left(1.08 \mathrm{mg} \mathrm{ml}^{-1}\right)$ were detected in animal sera after 5 h of $\beta$-LG administration (Figure 2).

\section{Oral administration of bovicin HC5 and ovalbumin induce} histological and morphometric alterations in the intestine of BALB/c mice

No alterations were identified in the liver and heart of animals from all the groups analyzed (data not shown). A significant decrease in the total number of spleen cells was observed in Bov and PC groups, when compared to the NC group (Figure 3).

The small intestine of the NC group presented a wellpreserved villi and crypts, with intact intestinal layers (Figure 4A and 4D). In the Bov group, the severity of the effects varied among the animals and major alterations were observed in the lamina propria (mild edema) and in the apical portion of the villi, with a "worst case scenario" being presented in Figure 4B and 4E. As expected, the animals from the PC group developed intestinal inflammation, characterized by inflammatory cell infiltration, tissue

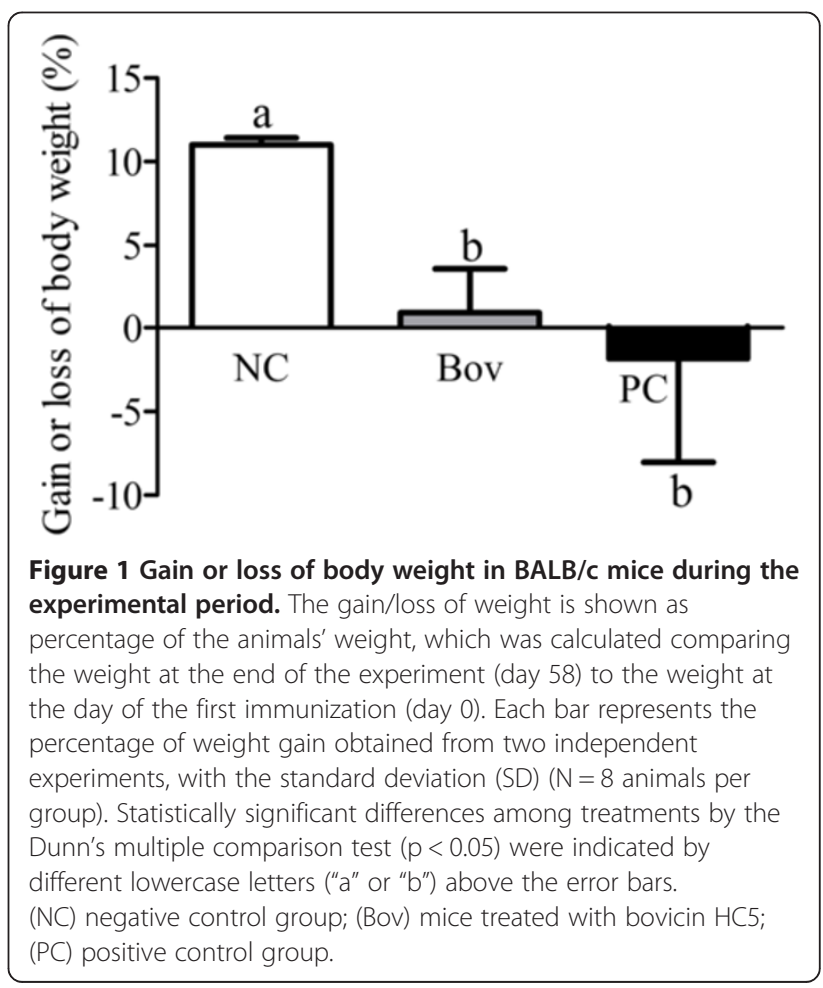




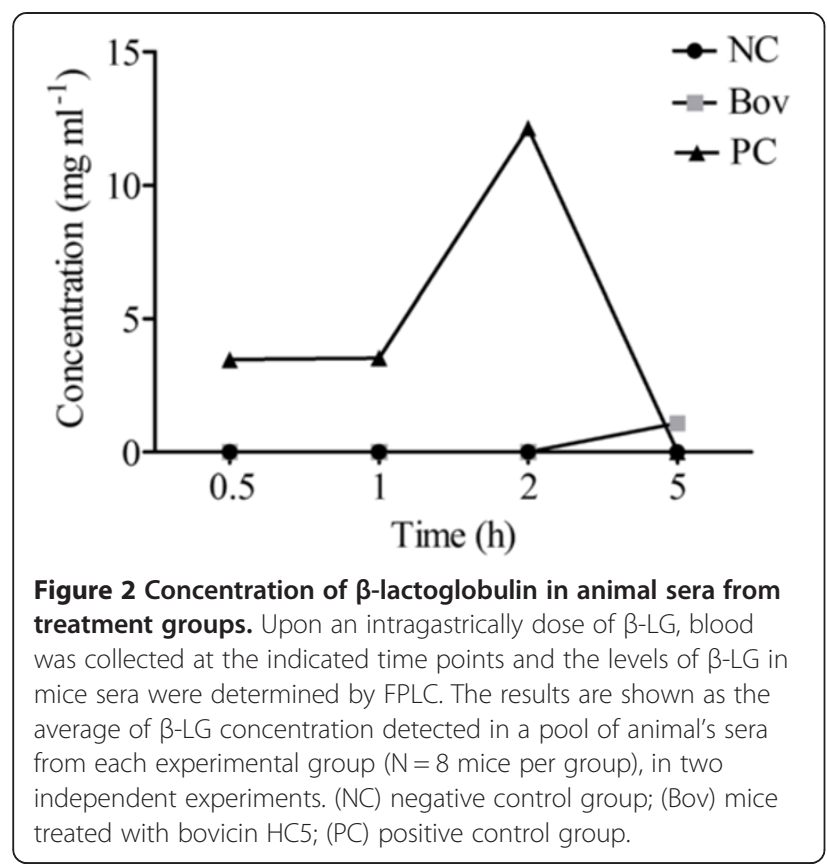

destruction, epithelial exulceration, edema and congestion of the lamina propria (Figure 4C and 4F).

Morphometric analysis of the small and large intestine of the animals treated with bovicin HC5 or ovalbumin showed some impairment of the intestinal structure integrity, but the severity of the alterations caused by bovicin $\mathrm{HC} 5$ and ovalbumin was clearly different.

The number of $\mathrm{PAS}^{+}$cells, which secrete only neutral mucopolysaccharides, did not differ among the groups (Figure 5A), and cells secreting exclusively acid mucins $\left(\mathrm{AB}^{+}\right.$cells) were not detected. The majority of goblet cells

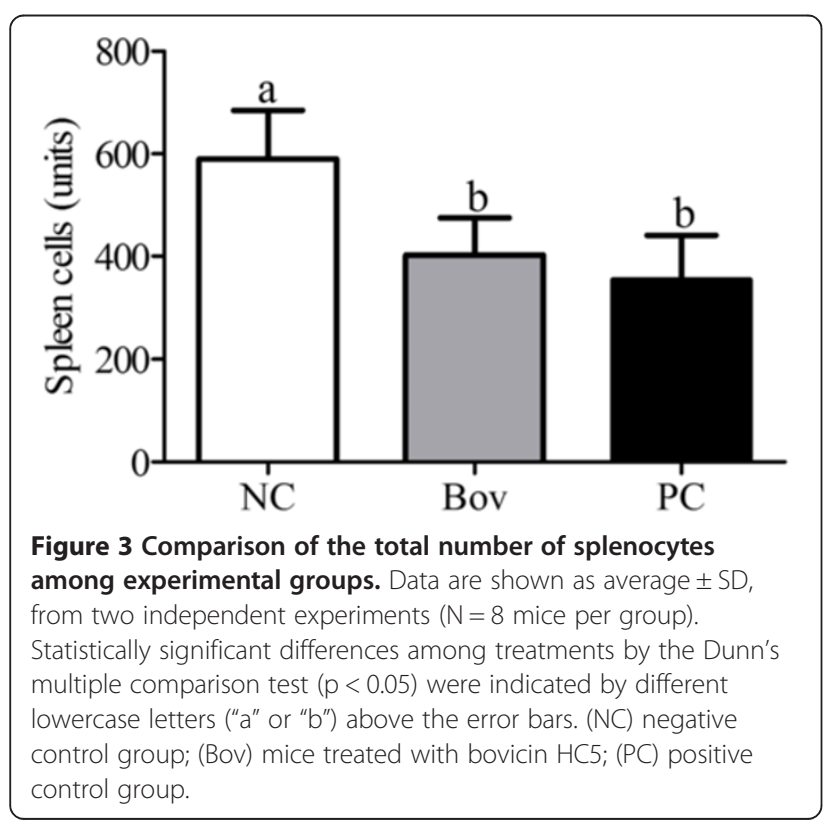

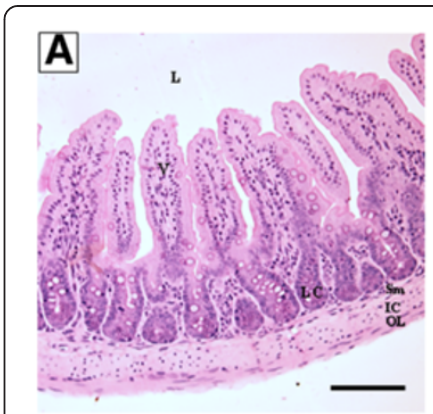
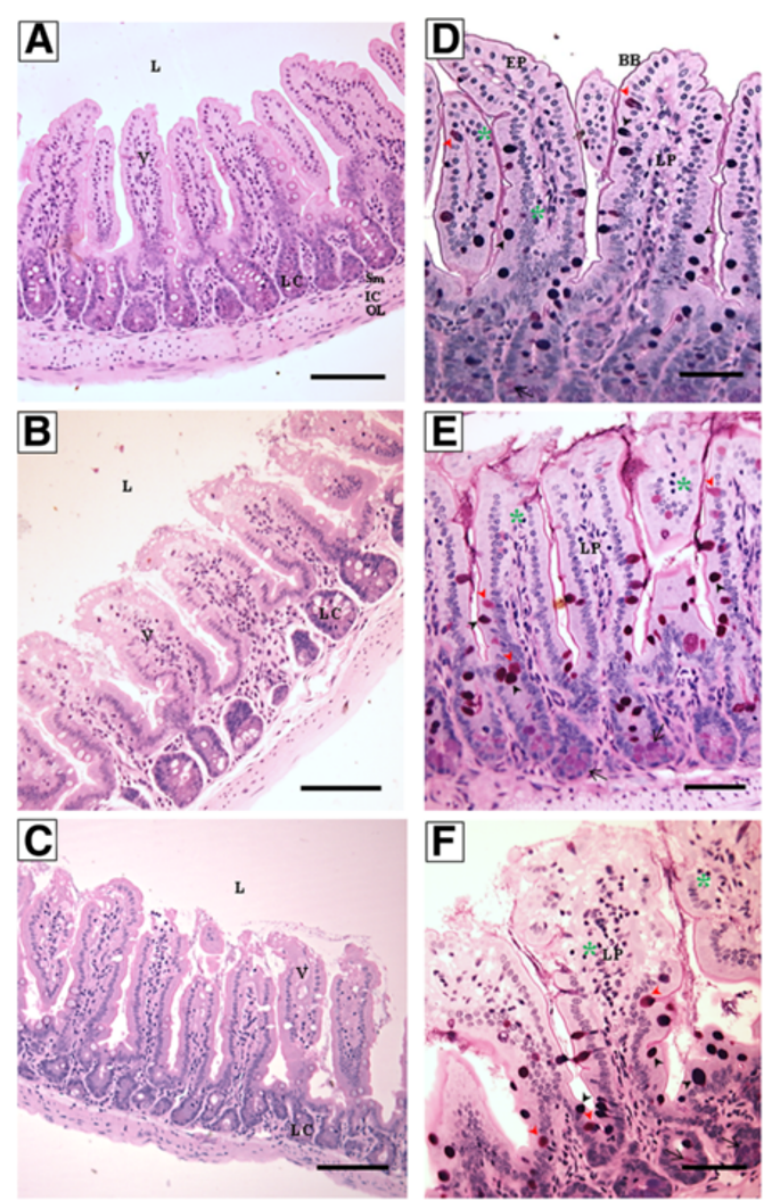

Figure 4 Photomicrographs of longitudinal sections of small intestine of the experimental groups. Jejunum segments were collected and processed for optical microscopy analysis at the end of the experiment (day 58) ( $N=8$ mice per group). ( $N C$ ), negative control group, figures $\mathbf{A}$ and $\mathbf{D}$; (Bov) mice treated with bovicin HC5, figures $\mathbf{B}$ and $\mathbf{E} ;(P C)$ positive control group, figures $\mathbf{C}$ and $\mathbf{F}$. The sections were stained with hematoxylin and eosin (HE; left panel) or PAS/Alcian Blue (right panel). Abbreviations: L: lumen; EP: simple cuboidal epithelium; BB: brush border; V: villum; LP: lamina propria; LC: Lieberkühn crypt; Sm: submucosa; IC: inner circular muscle layer; OL: outer longitudinal muscle layer. The asterisks indicate intraepithelial lymphocytes; simple arrow indicates Paneth cells. Black arrow head indicates goblet cells $\mathrm{PAS} / \mathrm{AB}^{+}$; red arrow head indicates $\mathrm{PAS}^{+}$cells. Right panel - Scale bar: 100 um; Left panel - Scale bar: $50 \mu \mathrm{m}$.

in $\mathrm{NC}$ group was PAS/AB ${ }^{+}$cells, which secrete both neutral and acidic mucopolysaccharides (83\% of the total number of goblet cells). The number of PAS/ $\mathrm{AB}^{+}$cells did not differ between the NC and Bov groups, but it was significantly reduced in $\mathrm{PC}$ group $(\mathrm{p}<0.05$, Figure $5 \mathrm{~B})$. No differences were observed in the total number of goblet cells in the small intestine of Bov group, when compared to the NC group. However, the total number of goblet cells in the small intestine of $\mathrm{PC}$ group was reduced when compared to Bov and $\mathrm{NC}$ groups $(\mathrm{p}<0.05$, Figure $5 \mathrm{C})$. 
Analysis of the Lieberkühn glands indicated hypertrophy of Paneth cells (Figure 6A) and an increase in the number of mitotic cells (Figure 6B) in Bov and PC groups when compared to the NC group ( $\mathrm{p}<0.05)$, although no differences were observed between Bov and PC groups $(\mathrm{p}>$ $0.05)$. No alteration on the number of mast cells on jejunum segments (mucosa and submucosa) was observed between Bov and NC groups, although a significant increase has been observed in PC group $(\mathrm{p}<0.05)$ (Figure 7). In $\mathrm{PC}$ group, the jejunum segments demonstrated a significant increase $(\mathrm{p}<0.05)$ in the number of mast cells from the mucosa and submucosa (Figure 7), when compared to Bov and NC groups.

In the small intestine of animals from the Bov group, significant villous atrophy accompanied by villi enlargement was observed. In PC group, the increase of the villous diameter was even more pronounced when compared to the Bov group $(\mathrm{p}<0.05)$, although the height of the villi was not altered, when compared to NC group (Figure 8).

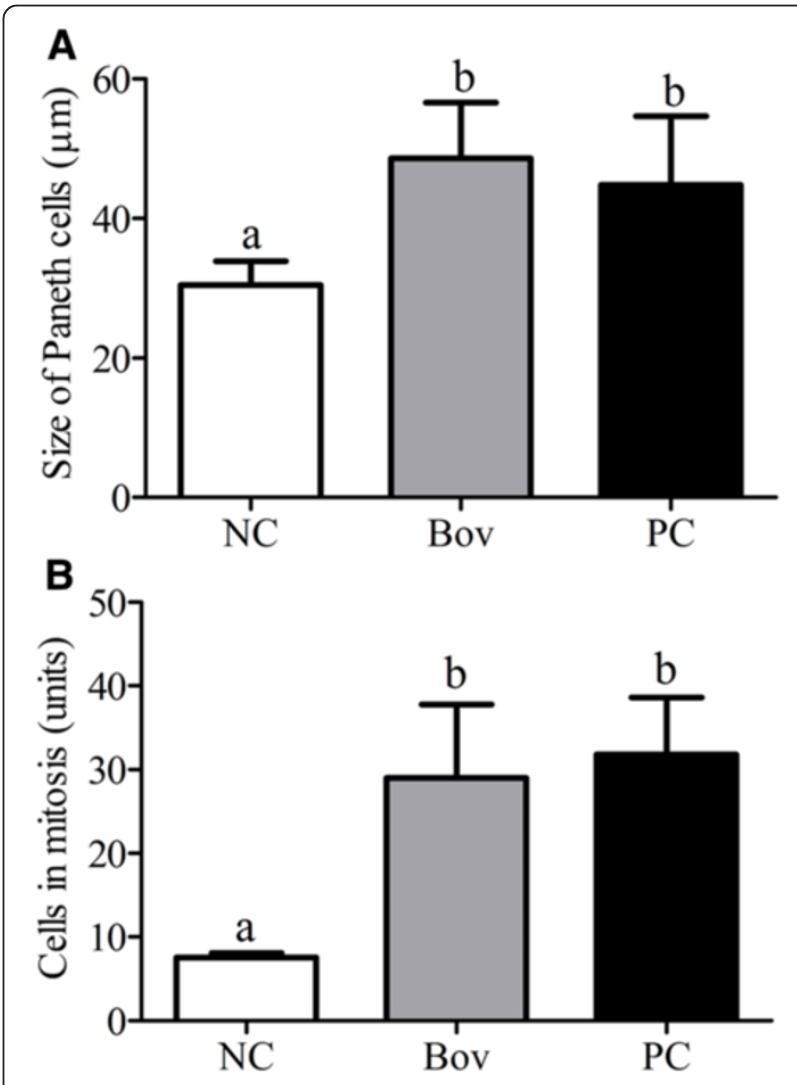

Figure 6 Analysis of the Lieberkuhn glands. Size of Paneth cells (A) and number of cells in mitosis (B) at the small intestinal crypts of the experimental groups. Data are shown as average \pm SD, from two independent experiments ( $N=8$ mice per group). Statistically significant differences among treatments by the Dunn's multiple comparison test $(p<0.05)$ were indicated by different lowercase letters ("a" or "b") above the error bars. (NC) negative control group; (Bov) mice treated with bovicin HC5; (PC) positive control group. 


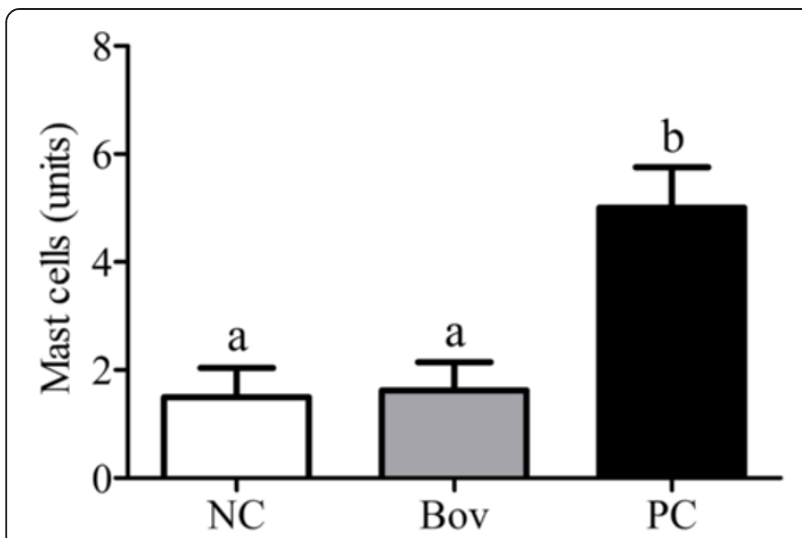

Figure 7 Number of mast cells in small intestine of the experimental groups. Longitudinal sections from jejunum segments were stained with toluidine blue/sodium borate (1\%), and the mast cells were counted in the mucosa and submucosa. Data are shown as average \pm SD, from two independent experiments ( $N$ $=8$ mice per group). Statistically significant differences among treatments by the Dunn's multiple comparison test $(p<0.05)$ were indicated by different lowercase letters ("a" or "b") above the error bars. (NC) negative control group; (Bov) mice treated with bovicin HC5; (PC) positive control group.

The large intestine of the NC group was normal and with a homogenous aspect (Figure 9A and 9B). The effects of bovicin HC5 and ovalbumin were less evident in the large intestine of the animals. No differences on epithelium structure or cellularity were detected in Bov group (Figure 9C), while a moderate edema at the lamina propria (Figure 9D) and a significant reduction at the mucosal thickness (Figure 10) were detected among the animals from the PC group $(\mathrm{p}<0.05)$.

\section{Assessment of the immunostimulatory effects on spleen and small intestine of animals treated with bovicin HC5 or ovalbumin}

There was no difference in relative gene expression of cytokines in the spleen when the means of the Bov and NC groups were compared. Only the IL-13 mRNA expression differed among the groups, with the PC group showing the highest expression levels in the spleen $(\mathrm{p}<$ 0.05 ) (Additional file 1). In the small intestine, the relative expression of IL-12, INF- $\gamma$ and TNF- $\alpha$ was significantly higher for the Bov group $(p<0.05$, Figure $11 \mathrm{~A}$, $11 \mathrm{~B}$ and 11E), while the IL-5, IL-13 and IL-4 mRNA expression was significantly higher in the PC group $(\mathrm{p}<$ 0.05 , Figure $11 \mathrm{C}, 11 \mathrm{D}$ and $11 \mathrm{H})$. The mRNA levels of TGF- $\beta$, IL-10 and IL-17 did not differ between the groups (Figure 11F, 11G and 11I).

\section{Discussion}

In this study, we used a murine model of food-induced enteropathy in order to compare the morphological and immunostimulatory effects of the orally administered
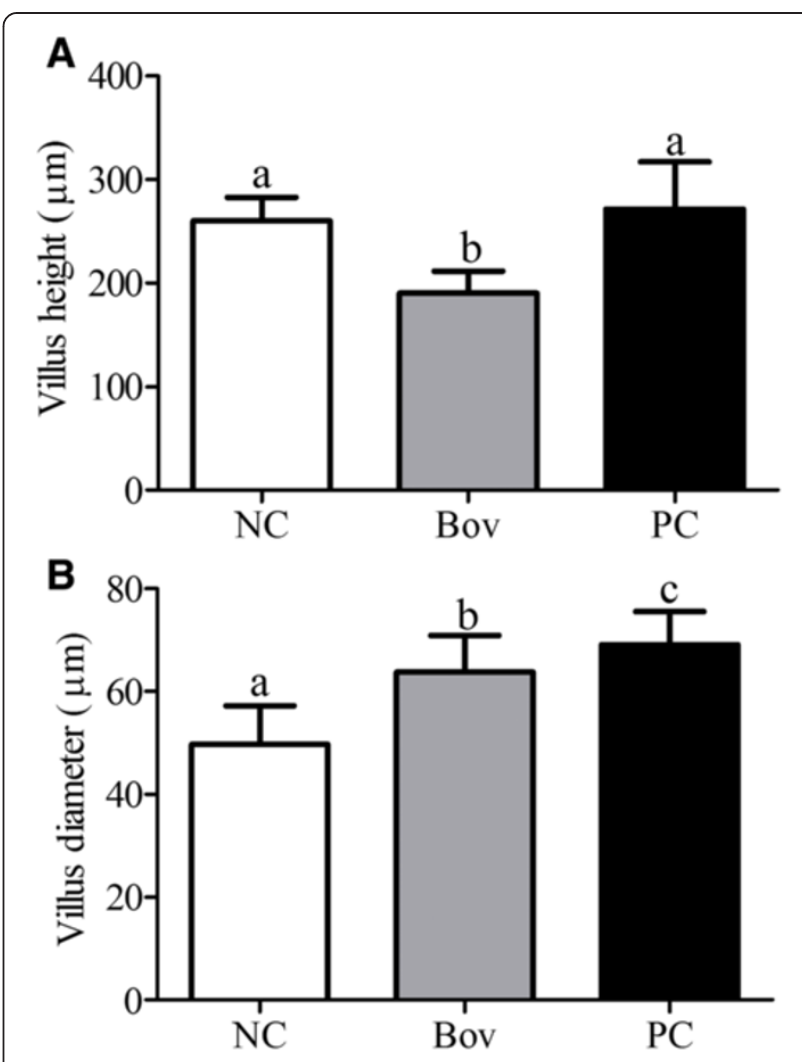

Figure 8 Morphometric analysis of the small intestinal villi. Panel (A) and panel (B) show the height and diameter of the small intestinal villi, respectively. Data were shown as average \pm SD, from two independent experiments ( $N=8$ mice per group). Statistically significant differences among treatments by the Dunn's multiple comparison test $(p<0.05)$ were indicated by different lowercase letters ("a", "b" or " $c$ ") above the error bars. (NC) negative control group; (Bov) mice treated with bovicin $\mathrm{HC}$; (PC) positive control group.

bovicin HC5. In our positive control group, the breakdown of mucosal tolerance was obtained by oral administration of the non-tolerogenic antigen ovalbumin (OVA). OVA has become a reference protein for immunological and biochemical studies, being widely used as an antigen for studying allergic diseases in mice [17].

The model used to induce food enteropathy worked properly, and an inflammatory reaction was developed in the small intestine. OVA administration altered the small intestinal architecture, increased protein permeability, caused edema and decrease the mucosal thickness in the large intestine. In contrast, upon oral administration of bovicin HC5, only minor histological alterations indicative of inflammation or alterations on permeability were observed, although an atrophy of the villi and destruction of the apical portion of the villi were detected in some regions of the small intestine.

The degree of impairment of the small intestine could explain the differences observed in weight gain between 

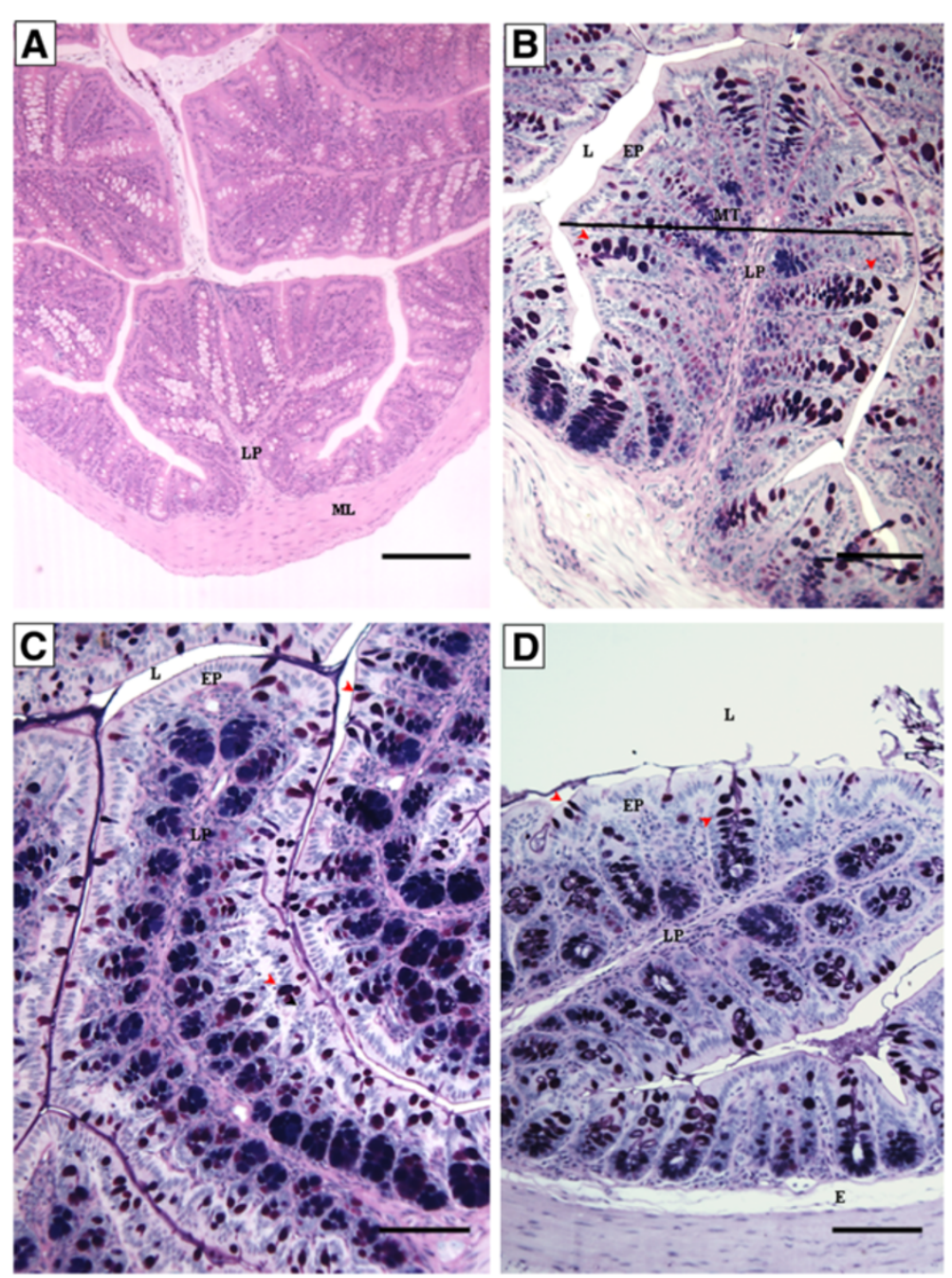

Figure 9 Photomicrographs of longitudinal sections of large intestine of the experimental groups. Large intestine segments were collected and processed for optical microscopy analysis at the end of the experiment (day 58) ( $N=8$ mice per group). (NC), negative control group, figures $\mathbf{A}$ and $\mathbf{B}$; (Bov) mice treated with bovicin HC5, figure $\mathbf{C}$; $(\mathrm{PC})$ positive control group, figure $\mathbf{D}$. The sections were stained with hematoxylin and eosin (HE; figure A) or PAS/Alcian Blue (figures B-D). Abbreviations: EP: simple cuboidal epithelium; LP: lamina propria; MT: mucosal thickness; E: edema; ML: muscle layer. Red arrow head indicates goblet cells. Scale bar $=200$ (figure A) or $100 \mu$ m (figures B, C and D).

Bov and PC groups throughout the experiment, since these alterations may have influenced the absorption of nutrients. Saldanha et al. [18] reported that BALB/c mice previously sensitized lost weight after challenging with OVA, which remained until the end of the experiment.

In normal conditions, the number of mast cells in the intestine is relatively constant, but hyperplasia can be observed during inflammatory reactions or during stages of remodeling/repair of inflammatory disorders [19]. As a result of the food enteropathy developed upon administration of OVA, we observed increased number of mast cells in the small intestine of PC group. However, no alterations were observed in the mast cell population from the Bov group.
Bacterial products or cell components may induce metaplasia, proliferation and hypersecretion of goblet cells [20]. In this study, animals treated with OVA showed reduced number of goblet cells in the small intestine, and a reduction in the secretion of acidic and neutral mucins. In contrast, the administration of bovicin HC5 did not alter the total number or the pattern of goblet cell secretion. The mucus protects the intestinal wall by limiting the absorption of antigens, and therefore, the hypersecretion of mucopolysaccharides was expected at the PC group, as a characteristic of allergic inflammation and as a result of increased IL-13 expression [21]; therefore, the reduction in the number of cells responsible for mucus secretion observed in PC group may not be related to the reduction 


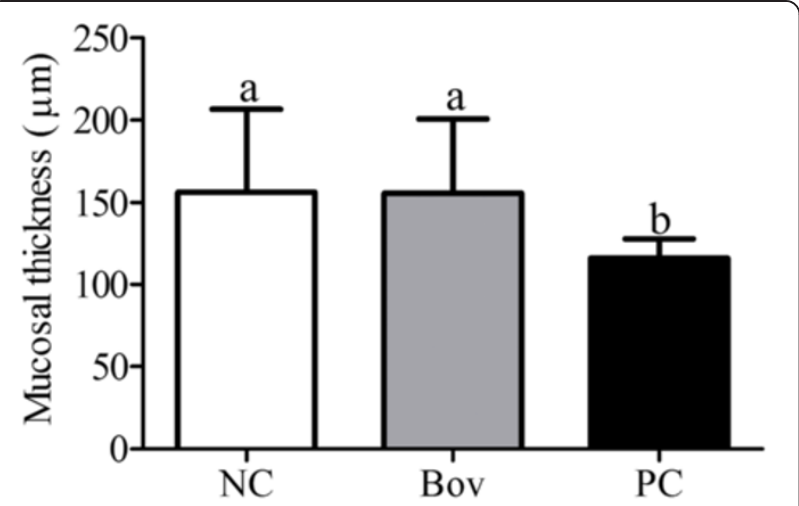

Figure 10 Comparison of the mucosal thickness of the large intestine among the experimental groups. Data are shown as average $\pm S D$, from two independent experiments ( $N=8$ mice per group). Statistically significant differences among treatments by the Dunn's multiple comparison test $(p<0.05)$ were indicated by different lowercase letters ("a" or "b") above the error bars. (NC) negative control group; (Bov) mice treated with bovicin HC5; (PC) positive control group in the secretion process per se, but to the limited count fields resulting from the destruction of the villi observed in $\mathrm{PC}$ group.

Similar to goblet cells, Paneth cells also play an important role in host intestinal defense mechanisms, contributing to the maintenance of the gastrointestinal barrier by secreting antimicrobial peptides and other compounds in response to bacteria and bacterial antigens [22,23]. The presence of antigens in the gastrointestinal tract also influence the expression and activity of key proteins involved in the regulation of cell proliferation [24]. Hypertrophy of Paneth cells and increased mitotic activity were observed in Bov and PC groups, indicating that despite the loss of villi architecture, secretion of antimicrobial compounds and tissue repair systems remained active, probably as a response to the injuries caused by bovicin $\mathrm{HC} 5$ and OVA in the small intestine.

Our results indicate that the effects of bovicin HC5 and ovalbumin administration are more pronounced in the intestine, which can explain the significant reduction in spleen cellularity observed in Bov and PC groups: immune cells probably migrated from the spleen to the intestine, where the main effects were observed.

OVA administration modulated the gut mucosal immunity in BALB/c mice towards significant $\mathrm{T}_{\mathrm{H}}$ 2-polarized response, increasing the relative expression of IL-4, IL-5 and IL-13 mRNA. Goya et al. [25] also observed increased mRNA levels of the $\mathrm{T}_{\mathrm{H}} 2$ cytokines IL-4, IL-5 and IL-13, as well as a decrease of INF- $\gamma$ expression in the lungs of OVA-treated mice. A down modulation of regulatory mechanisms, with reduction of TGF- $\beta$ and IL-10 expression, may be involved in the development of food allergy
[26], but this pattern of cytokine expression, although expected, was not observed in this study.

The modulation of the host immune system induced by bacteriocins is a phenomenon much less understood when compared to other peptides or proteins, such as proteins extracted from mushrooms (such as LZ-8 $(13 \mathrm{kDa})$ [27], Fip-vvo (15 kDa) [28] and FIP-fve (114 aa) [29]) and host-defense peptides [30,31].

In contrast to the $\mathrm{T}_{\mathrm{H}}$ 2-polarized response elicited by OVA, higher mRNA expression for the $\mathrm{T}_{\mathrm{H}} 1$ cytokines TNF- $\alpha$, IL-12 and INF- $\gamma$ were observed in the intestine of bovicin HC5-fed mice. Liu et al. [32] also demonstrated significant induction of IFN- $\gamma$ after administration of the yam tuber storage protein dioscorin. Human cathelicidin LL-37 modulated the activity of IFN- $\gamma$ on a variety of cell types [33], and pre-treatment with LL-37 induced IFN- $\gamma$ production by monocytes, enhancing monocyte-derived dendritic cell functions, such as IL-12 secretion and $\mathrm{T}_{\mathrm{H}} 1$-polarized co-stimulatory activity [34].

\section{Conclusions}

In the present work, for the first time, the effects of the oral administration of bovicin HC5 to an animal model were described. The bovicin HC5 concentration administrated to the animals (micromolar range) was greater than the quantities required for in vitro antimicrobial activity (nanomolar range). We have previously demonstrated that bovicin $\mathrm{HC}$, in higher concentrations, was able to permeabilize membranes in an unspecific way [13], but one should bear in mind that antimicrobial peptides can also modulate the microbial community composition in the intestine which could explain the partial destruction of small intestine cells caused by bovicin HC5 administration. Nonetheless, the impairment of the intestinal cells induced by bovicin $\mathrm{HC} 5$ neither altered the gut permeability nor was typical of an enteropathy process. Regarding the immunostimulatory effects, the results confirmed that bovicin $\mathrm{HC} 5$ was able to stimulate the immune system of BALB/c mice at local level (gut immune system), by influencing the cytokine release towards $\mathrm{T}_{\mathrm{H}} 1$-polarized response.

Proper pharmacokinetic studies will be needed to determine if bovicin $\mathrm{HC} 5$ can resist passage through the adverse conditions in the GI tract (low $\mathrm{pH}$, presence of peptidolytic and proteolytic enzymes), but it should be noted that animals treated with bovicin HC5 showed more pronounced effects in the intestine compared to the animals in the negative control groups. These results suggest that the oral administration of bovicin HC5 might be a promising strategy to control microbial infections, manipulate microbial community composition or modulate immunological responses in the GI tract of the host animal. 

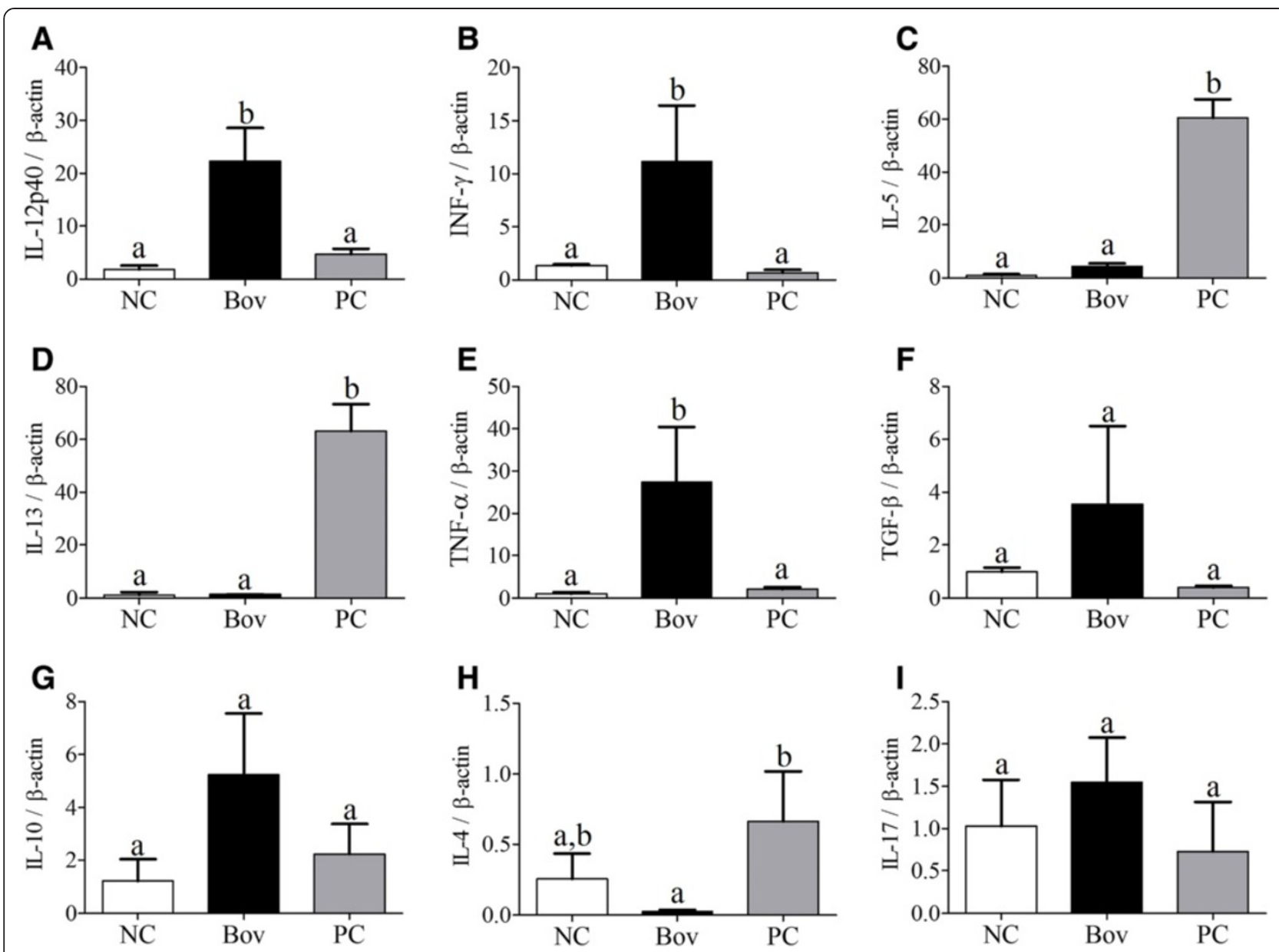

Figure 11 Cytokine production in small intestine of five-week old female BALB/c mice treated with bovicin $\mathrm{HC5}$ or ovalbumin. The relative expression of IL-12p40 (A), IFN- $\gamma(\mathbf{B})$, IL-5 (C), IL-13 (D), TNF-a (E), TGF- $\beta$ (F), IL-10 (G), IL-4 (H) and IL-17 (I) mRNA was determined by real time-PCR and calculated by reference to the $\beta$-actin in each sample, using the threshold cycle $(\mathrm{Ct})$ method. Results are shown as the mean value \pm SD of duplicate samples from three independent mice within the NC, Bov and PC groups. Differences among treatments were indicated by different lowercase letters and were considered statistically significant by the Bonferroni multiple comparison test $(p<0.05)$. (NC) negative control group; (Bov) mice treated with bovicin HC5; (PC) positive control group.

\section{Methods}

\section{Streptococcus bovis $\mathrm{HC} 5$ and bovicin $\mathrm{HC} 5$}

Streptococcus bovis HC5 growth and bovicin HC5 extraction were performed as previously described [11]. Purification of bovicin HC5 was performed by reversed phase-HPLC [13] and the purity of bovicin HC5 was confirmed by electrospray mass spectrometry to be always greater than $95 \%$.

Bovicin HC5 stock solutions $\left(1 \mathrm{mg} \mathrm{ml}^{-1}\right.$ in PBS $(10 \mathrm{mM}$, $\mathrm{pH}$ 7.2)) were stored at $-20^{\circ} \mathrm{C}$ until use. Protein concentration was determined using a bicinchoninic acid protein assay (Pierce Chemical Corp., Bonn, Germany), with bovine serum albumin as the standard.

\section{Experimental animals}

The BALB/c mice used in this study were housed in an animal facility at the Universidade Federal de Viçosa, according to standards and guidelines as set forth in the Animal Welfare Legislation, the Guide for the Care and Use of Laboratory Animals, the Association for the Assessment and Accreditation of Laboratory Animal Care (AAALAC) and the National Council for Animal Experimentation Control (CONCEA), following approval by the Institutional Animal Care and Use Committee (IACUC) of the Universidade Federal de Viçosa under the protocol number CEUA/UFV 97/2011.

Five-week-old female BALB/c mice were randomly divided into three experimental groups: Group 1, untreated mice (negative control, NC group); Group 2, mice given purified bovicin HC5 (Bov group); Group 3, mice given ovalbumin (Sigma Chemicals Co., St. Louis, MO, 99\% of purity) (positive control, PC group). Two independent experiments were performed and a total number of eight animals were used per experimental group. 
Table 1 Sequences of sense (S) and antisense (AS) primers used for real time-RT-PCR analysis (18)

\begin{tabular}{|c|c|}
\hline Primers & Sequences \\
\hline$\beta$-actin S & $5^{\prime}$ AGC TGC GTT TTA CAC CCT Tा $3^{\prime}$ \\
\hline$\beta$-actin AS & $5^{\prime}$ AAG CCA TGC CAA TGT TGT CT $3^{\prime}$ \\
\hline IL-10 S & $5^{\prime}$ TGG ACA ACA TAC TGC TAA CC $3^{\prime}$ \\
\hline IL-10 AS & $5^{\prime}$ GGA TCA TाT CCG ATA AGG CT 3' \\
\hline IL-4 S & $5^{\prime}$ CTG ACG GCA CAG AGC TAT TGA $3^{\prime}$ \\
\hline IL-4 AS & $5^{\prime}$ TAT GCG AAG CAC CTT GGA AGC $3^{\prime}$ \\
\hline IL-5 S & $5^{\prime}$ GAG GTT ACA GAC ATG CAC CAT T 3' \\
\hline IL-5 AS & $5^{\prime}$ TCA GTT GGT AAC ATG CAC AAA G 3' \\
\hline IL-13 S & $5^{\prime}$ ACC AAC ATC TCC AAT TGC AA $3^{\prime}$ \\
\hline IL-13 AS & $5^{\prime}$ ATG CAA TAT CCT CTG GGT CC $3^{\prime}$ \\
\hline TNF-a S & $5^{\prime}$ TGT GCT CAG AGC TाT CAA CAA $3^{\prime}$ \\
\hline TNF-a AS & $5^{\prime}$ CTT GAT GGT GGT GCA TGA GA $3^{\prime}$ \\
\hline $\mathrm{IL}-12 \mathrm{p} 40 \mathrm{~S}$ & $5^{\prime}$ AGC ACC AGC TTC TTC ATC AGG $3^{\prime}$ \\
\hline IL-12 p40 AS & $5^{\prime}$ GCG CTG GAT TCG AAC AAA G $3^{\prime}$ \\
\hline IFN- $-\mathrm{S}$ & $5^{\prime}$ GCA TCT TGG CTT TGC AGC T $3^{\prime}$ \\
\hline IFN-ץ AS & $5^{\prime}$ CCT TाT TCG CCT TGC TGT TG $3^{\prime}$ \\
\hline TGF- $\beta$ S & $5^{\prime}$ GCT GAA CCA AGG AGA CGG AAT $3^{\prime}$ \\
\hline TGF- $\beta$ AS & $5^{\prime}$ GCT GAT CCC GTT GAT TTC CA 3' \\
\hline IL-17 S & $5^{\prime}$ GCT CCA GAA GGC CCT CAG A 3' \\
\hline IL-17 AS & $5^{\prime}$ CTT TCC CTC CGC ATT GAC A $3^{\prime}$ \\
\hline
\end{tabular}

The sensitization procedure was developed based on previously established protocols [18]. Mice from the Bov group were subcutaneously sensitized with bovicin HC5 ( $4 \mu \mathrm{g} / \mathrm{g}$ animal weight/day or approximately $70 \mu \mathrm{g} / \mathrm{animal}$ [35]), while animals from the PC group were sensitized with ovalbumin $\left(100 \mu \mathrm{l}\right.$ of a $1 \mathrm{mg} \mathrm{ml}^{-1}$ stock solution in sterile ultrapure water, or $100 \mu \mathrm{g}$ OVA/animal). Aluminum hydroxide was used as adjuvant $\left(50 \mu \mathrm{l} ; 20 \mathrm{mg} \mathrm{ml}^{-1}\right.$ stock solution in sterile saline) at the first sensitization (day 0). After three weeks, each mouse group was subcutaneously boosted (without the use of adjuvant) with the respective substances (second sensitization, day 21). The NC group was sensitized with sterile PBS (10 mM, pH 7.2), using the same procedure described above.

PBS, bovicin HC5 or ovalbumin $(100 \mu \mathrm{l})$ were administered without adjuvant to the NC, Bov and PC groups, respectively, by daily gavages (18-gauge stainless steel feeding needles). Oral administration started one week after the second sensitization (day 28) and continued for 30 days uninterruptedly (day 58 ). The mice were weekly weighted and behavior, general appearance and adverse reactions were monitored daily.

\section{Gut permeability}

The gut permeability was determined by the uptake of $\beta$-lactoglobulin ( $\beta$-LG) following challenge ([36], with modifications]). At the end of the trial period (day 58), the animals of the NC, Bov and PC groups, were orally challenged with $200 \mu \mathrm{l}$ of the respective samples (PBS, bovicin HC5 or ovalbumin). After thirty minutes, the animals received an oral dose of $\beta$-LG $\left(200 \mu \mathrm{l} ; 100 \mathrm{mg} \mathrm{ml}^{-1}\right.$ solution in distilled water) (Sigma Chemicals Co., St. Louis, MO, $90 \%$ of purity).

Blood samples were collected from the orbital plexus under light isoflurane anesthesia, after $0.5,1,2$ and $5 \mathrm{~h}$ of the $\beta$-LG administration. The samples were kept at room temperature for 2 hours, and the sera were centrifuged (Eppendorf $^{\circledR}$, Centrifuge 5415C, Hamburg, Germany) at $12,000 \times \mathrm{g}, 5 \mathrm{~min}$, room temperature. Sera were used for the quantification of $\beta$-LG by FPLC, using a cationic change column (Mono Q HR 5/5). The column was equilibrated with buffer A (20 mM Tris) and the $\beta$-LG was eluted with a linear gradient of 25 to $50 \%$ buffer B $(20 \mathrm{mM}$ Tris, $1 \mathrm{M} \mathrm{NaCl}$ ), $22^{\circ} \mathrm{C}$, and flow rate of $1 \mathrm{ml} \mathrm{min}^{-1}$. Absorbance was monitored at 220 and $280 \mathrm{~nm}$.

The concentration of $\beta$-LG in animal sera was determined using a calibration curve with known concentrations of $\beta$-LG $\left(0 ; 6.25 ; 12.5 ; 25.0 ; 50.0 \mathrm{mg} \mathrm{ml}^{-1}\right)$ mixed to pre-immune serum of the animals from each group. The pre-immune serum corresponded to the sera collected prior to the initial sensitization procedure. Serum samples before $\beta$-LG administration were used as negative control. All analyses were performed in duplicate.

\section{Histological and morphometric analysis}

On day 58 the heart, liver, spleen and gut of the all the mice were aseptically collected, washed in PBS buffer $(10 \mathrm{mM}$, $\mathrm{pH}$ 7.2), fixed in Carson formalin solution [37], dehydrated and embedded in resin (Historesin ${ }^{\circledR}$, Leica). Transverse and longitudinal, $3 \mu \mathrm{m}$ thick tissue sections were obtained and stained with hematoxylin and eosin (H\&E), toluidine blue/ sodium borate (1\%) or with Alcian Blue ( $\mathrm{pH} 2.5)$ combined with periodic acid-Schiff (PAS) [38], depending on the histological analysis that would be performed.

Ten fields of longitudinal sections stained with H\&E were randomly selected and visualized with a $10 \times$ objective lens in order to perform the morphological analysis of the organs selected (villi height and width were determined from an area of $17 \mathrm{~mm}^{2}$ per animal; for mucosal thickness, an average of twenty measurements were obtained from each animal). The spleen cells were counted using ten fields of longitudinal sections visualized with a $40 \times$ objective lens, in an area of $0.23 \mathrm{~mm}^{2}$ per animal. For quantitative and qualitative analysis of goblet cells, ten fields of longitudinal sections (area of $1 \mathrm{~mm}^{2}$ ) stained with Alcian Blue-PAS were randomly selected and visualized with a $20 \times$ objective lens; the mucins produced by goblet cells were identified by differential staining (acid mucins in blue, neutral mucins in red, and mixed acid and neutral mucins in purple). The 
mast cells were counted using ten longitudinal sections stained with toluidine blue/sodium borate (1\%) and visualized with a $40 \times$ objective lens; an area equivalent to 20 jejunum villi (mucosa and submucosa) was evaluated for each animal.

Digital images were captured with a light microscope (Olympus AX 60), coupled to a digital camera (Q-Color 3, Olympus). The morphometric analyzes were performed with the image analysis program Image Pro Plus 4.0 for Windows (Media Cybernetics). The results were shown as mean values \pm standard error of the mean.

\section{Analysis of relative gene expression by real-time PCR}

The whole spleen and jejunum segments (100 mg of tissue) were aseptically removed, washed in sterile PBS $(10 \mathrm{mM}$, $\mathrm{pH}$ 7.2), and individually manipulated. Cells obtained from the spleen were washed with saline $(0.85 \%)$, centrifuged at 7,500 $\times g$ for 5 min (Eppendorf $^{\circledR}$, Centrifuge $5415 \mathrm{C}$, Hamburg, Germany), at room temperature, and the erythrocytes were lysed using a hemolytic solution $(155 \mathrm{mM}$ $\mathrm{NH}_{4} \mathrm{Cl}, 10 \mathrm{mM} \mathrm{KHCO} 3, \mathrm{pH}$ 7.2). The splenocytes were centrifuged again and the supernatant was discarded. A jejunum segment of $6 \mathrm{~cm}$ was removed and washed three times with saline $(0.85 \%)$, for removal of waste.

The splenocytes and jejunum segments were homogenized in Tri Reagent $\left(\mathrm{Sigma}^{\circledR}\right)$ to isolate total RNA, following the manufacturer's instructions. RNA yield was analyzed spectrophotometically at $260 \mathrm{~nm}$ (Ultraspec 3000, Pharmacia Biotech, Piscataway, NJ). From each group (NC, Bov and $\mathrm{PC}$ ), three samples from different animals showing highest RNA yield were chosen for cDNA synthesis. Complementary DNA (cDNA) was synthesized through a RT reaction (M-MuLV reverse transcriptase, Promega), according to the manufacturer's instructions. Real-time RT-PCR was conducted with a final volume of $25 \mu \mathrm{L}$ containing 2.5 ng of cDNA, SYBR-green PCR Master Mix (Applied Biosystems, Warrington, UK), oligo(dT) cDNA as the PCR template, and $450 \mathrm{nM}$ specific primers. Real-time RT-PCR was performed on the Gene Amp ${ }^{\circledR} 5700$ Sequence Detection System Version 1.3 (Applied Biosystems) and the cycling parameters used were $95^{\circ} \mathrm{C}$ for $10 \mathrm{~min}, 40$ cycles at $94^{\circ} \mathrm{C}$ for $1 \mathrm{~min}, 56^{\circ} \mathrm{C}$ for $1 \mathrm{~min}$, and $72^{\circ} \mathrm{C}$ for $2 \mathrm{~min}$, followed by the standard denaturation curve. The sequences of murine primers used in this study (Table 1) were previously described [9].

The results were demonstrated as relative level of gene expression in the experimental group, by reference to the $\beta$-actin gene in each sample, using the cycle threshold $(\mathrm{Ct})$ method. Measurements were conducted in duplicates and the fold increase expression was calculated by using the expression $2^{\wedge} \mathrm{DCt}$, according to the instructions from Applied Biosystems User's Bulletin \#2 (P/N 4303859). Results were shown as mean values \pm standard deviation.

\section{Statistical analysis}

The means of the groups were evaluated by analysis of variance (ANOVA) followed by the Dunn's or Bonferroni's post test. A probability value of less than 0.05 was considered statistically significant, and all the comparisons were performed using the GraphPad Prism 5.00 software (GraphPad Software, San Diego California, USA).

\section{Additional file}

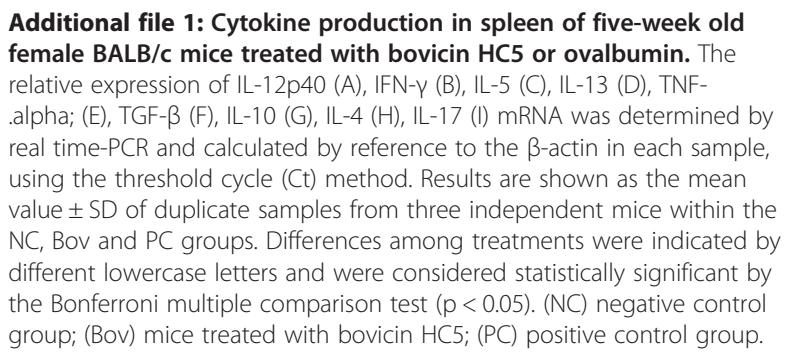

Competing interests

The authors have declared no competing interests.

\section{Authors' contributions}

ADP performed all the experiments. KMF carried out the histological analysis. RSD and ASR participated in the collection of immunological data. LLO, CAN and SOP participated in the analysis and interpretation of data. ADP, HCM and SOP participated in the design of the study. ADP and HCM prepared the manuscript. All authors read and approved the final manuscript.

\section{Acknowledgments}

A.D.P. was supported by a fellowship from the Coordenação de Aperfeiçoamento de Pessoal de Nível Superior (Grant Number AUXPE/PNPD 2439/2011, Brasília, Brazil). This work was supported by the Conselho Nacional de Desenvolvimento Científico e Tecnológico (Grant Number 201179/2009-1) and by a Grant from the Fundação de Amparo à Pesquisa de Minas Gerais (Belo Horizonte, Brazil).

\section{Author details}

'Departamento de Microbiologia, Universidade Federal de Viçosa, Viçosa, Minas Gerais, Brazil. ²Departamento de Biologia Geral, Universidade Federal de Viçosa, Viçosa, Minas Gerais, Brazil.

Received: 3 August 2012 Accepted: 21 February 2013

Published: 27 March 2013

\section{References}

1. Delves-Broughton J: Nisin as a food preservative. Food Aust 2005, 57:525-527.

2. Gálvez A, López RL, Abriouel H, Valdivia E, Ben ON: Application of bacteriocins in the control of foodborne pathogenic and spoilage bacteria. Crit Rev Biotechnol 2008, 28:125-152.

3. Gänzle MG, Weber S, Hammes WP: Effect of ecological factors on the inhibitory spectrum and activity of bacteriocins. Int J Food Microbio/ 1999, 46:207-217.

4. Toke O: Antimicrobial peptides: new candidates in the fight against bacterial infections. Biopolymers 2005, 580:717-735.

5. Belguesmia Y, Madi A, Sperandio D, Merieau A, Feuilloley M, Prévost H, Drider D, Connil N: Growing insights into the safety of bacteriocins: the case of enterocin S37. Res Microbiol 2011, 162:159-163.

6. Pariza MW, Foster EM: Determining the safety of enzyme used in food processing. J Food Protect 1983, 46:453-468.

7. Pariza MW, Cook M: Determining the safety of enzymes used in animal feed. Regul Toxicol Pharmacol 2010, 56:332-342. 
8. FDA. U.S. Food and Drug Administration: Toxicological principles for the safety assessment of direct food additives and color additives used in food. Washington, D.C: U.S. FDA; 1993.

9. Bhunia AK: Monoclonal antibody-based enzyme immunoassay for pediocins of Pediococcus acidilactici. Appl Environ Microbiol 1994, 60:2692-2696.

10. Bhunia AK, Johnson MG, Ray B, Elden EL: Antigenic property of pediocin AcH produced by Pediococcus acidilactici H. J Appl Bacteriol 1990, 69:211-215.

11. Mantovani HC, Hu H, Worobo RW, Russell JB: Bovicin HC5, a bacteriocin from Streptococcus bovis HC5. Microbiology 2002, 148:3347-3352.

12. Houlihan AJ, Russell JB: Factors affecting the activity of bovicin HC5, a bacteriocin from Streptococcus bovis HC5: release, stability and binding to target bacteria. J Appl Microbiol 2006, 100:168-174.

13. Paiva AD, Breukink E, Mantovani HC: Role of lipid II and membrane thickness in the mechanism of action of the lantibiotic bovicin HC5. Antimicrob Agents Chemother 2011, 55:5284-5293.

14. Paiva AD, Oliveira MD, de Paula SO, Baracat-Pereira MC, Breukink E, Mantovani HC: Toxicity of bovicin HC5 against mammalian cell lines and the role of cholesterol in bacteriocin activity. Microbiology 2012, 158:2851-2858

15. Russell JB, Mantovani HC: The bacteriocins of ruminal bacteria and their potential as an alternative to antibiotics. J Mol Microbiol Biotechnol 2002, 4:347-355.

16. de Carvalho AA, Vanetti MC, Mantovani HC: Bovicin HC5 reduces thermal resistance of Alicyclobacillus acidoterrestris in acidic mango pulp. J Appl Microbiol 2008, 104:1685-1691.

17. Lloyd CM, Gonzalo JA, Coyle AJ, Gutierrez-Ramos JC: Mouse models of allergic airway disease. Adv Immunol 2001, 77:263-295.

18. Saldanha JCS, Gargiulo DL, Silva SS, Carmo-Pinto FH, Andrade MC, AlvarezLeite Jl, Teixeira MM, Cara DC: A model of chronic lgE mediated food allergy in ovalbumin-sensitized mice. Braz J Med Biol Res 2004, 37:809-816.

19. Bischoff SC, Sellge G: Mast cell hyperplasia: Role of cytokines. Int Arch Allergy Immunol 2002, 127:118-122.

20. Nell MJ, Grote JJ: Effects of bacterial toxins on air-exposed cultured human respiratory sinus epithelium. Ann Otol Rhinol Laryngol 2003, 112:461-468.

21. Zimmermann N, Hershey GK, Foster PS, Rothenberg ME: Chemokines in asthma: cooperative interaction between chemokines and IL-13. J Allergy Clin Immunol 2003, 111:227-242.

22. Ayabe T, Satchell D, Wilson C, Parks W, Selsted M, Ouellette A: Secretion of microbicidal alpha-defensins by intestinal Paneth cells in response to bacteria. Nat Immunol 2000, 1:113-118.

23. Keshav S: Paneth cells: leukocyte-like mediators of innate immunity in the intestine. J Leukoc Biol 2006, 80:500-508.

24. Sergent TT, Ribonnet L, Kolosova A, Garsou S, Schaut A, de Saeger S, Peteghem CV, Larodelle Y, Puseemier L, Scheneider Y: Molecular and cellular effects of food contaminants and secondary plant components and their plausible interactions at the intestinal level. Food Chem Toxicol 2008, 46:813-841.

25. Goya I, Villares R, Zaballos A, Gutiérrez J, Kremer L, Gonzalo JA, Varona R, Carramolino L, Serrano A, Pallares P, Criado LM, Kolbeck R, Torres M, Coyle AJ, Gutiérrez-Ramos JC, Martínez C, Márquez G: Absence of CCR8 does not impair the response to ovalbumin-induced allergic airway disease. J Immunol 2003, 170:2138-2146.

26. Cardoso CR, Teixeira G, Provinciatto PR, Godoiz DF, Ferreira BR, Milanezi CM, Ferraz DB, Rossi MA, Cunhaz FQ, Silva JS: Modulation of mucosal immunity in a murine model of food-induced intestinal inflammation. Clin Exp Allergy 2008, 38:338-349.

27. Kino K, Yamashita A, Yamaoka K, Watanabe J, Tanaka S, Ko K, Shimizu K, Tsunoo $\mathrm{H}$ : Isolation and characterization of a new immunomodulatory protein, ling zhi-8 (LZ-8), from Ganoderma lucidium. J Biol Chem 1989, 264:472-478.

28. Hsu HC, Hsu Cl, Lin RH, Kao CL, Lin JY: Fip-vvo, a new fungal immunomodulatory protein isolated from Volvariella volvacea. Biochem J 1997, 323:557-565.

29. $\mathrm{Ko} J \mathrm{~L}, \mathrm{Hsu} \mathrm{Cl}$, Lin $\mathrm{RH}, \mathrm{KaO} \mathrm{CL}$, Lin JY: A new fungal immunomodulatory protein, FIP-fve isolated from the edible mushroom, Flammulina velutipes and its complete amino acid sequence. Eur J Biochem 1995, 228:244-249.
30. Yang D, Biragyn A, Hoover DM, Lubkowski J, Oppenheim JJ: Multiple roles of antimicrobial defensins, cathelicidins, and eosinophil-derived neurotoxin in host defense. Annu Rev Immunol 2004, 22:181-215.

31. Scott MG, Dullaghan E, Mookherjee N, Glavas N, Waldbrook M, Thompson A, Wang A, Lee K, Doria S, Hamill P: An anti-infective peptide that selectively modulates the innate immune response. Nat Biotechnol 2007, 25:465-472

32. Liu YW, Liu JC, Huang CY, Wang CK, Shang HF, Hou WC: Effects of oral administration of yam tuber storage protein, dioscorin, to BALB/C mice for 21-days on immune responses. J Agric Food Chem 2009, 57:9274-9279.

33. Nijnik A, Pistolic J, Wyatt A, Tam S, Hancock REW: Human cathelicidin peptide LL-37 modulates the effects of IFN- $\gamma$ on APCs. J Immuno/ 2009, 183:5788-5798.

34. Davidson DJ, Currie AJ, Reid GS, Bowdish DM, MacDonald KL, Ma RC, Hancock REW, Speert DP: The cationic antimicrobial peptide LL-37 modulates dendritic cell differentiation and dendritic cell-induced $T$ cell polarization. J Immunol 2004, 172:1146-1156.

35. Akiyama H, Teshima R, Sakushima J, Okunuki H, Goda Y, Sawada J, Toyoda M: Examination of oral sensitization with ovalbumin in Brown Norway rats and three strains of mice. Immunol Lett 2001, 78:1-5.

36. Knippels LMJ, Houben GF, Spanhaak S, Penninks AH: An oral sensitization model in Brown Norway rats to screen for potential allergenicity of food proteins. Methods 1999, 19:78-82.

37. Carson FL, Martin JH, Lynn JA: Formalin fixation for electron microscopy: a re-evaluation. Am J Clin Pathol 1973, 59:365-373.

38. Bancroft JD, Stevens A: Theory and practice of histological techniques. 4th edition. London: Churchill Livingstone; 1996.

doi:10.1186/1471-2180-13-69

Cite this article as: Paiva et al:: Safety evaluation of the antimicrobial peptide bovicin HC5 orally administered to a murine model. BMC Microbiology 2013 13:69.

\section{Submit your next manuscript to BioMed Central and take full advantage of:}

- Convenient online submission

- Thorough peer review

- No space constraints or color figure charges

- Immediate publication on acceptance

- Inclusion in PubMed, CAS, Scopus and Google Scholar

- Research which is freely available for redistribution 